\title{
Introduction: Creative Critical Shakespeares
}

\author{
Rob Conkie and Scott Maisano
}

Here is a beginning of this special issue on 'Creative Critical Shakespeares':

The range of creative responses to Shakespeare has expanded recently to include critical writing that is evocative, affective, and performative. This seminar invites papers - on any Shakespeare-related topic - that integrate creative and critical modes of writing. The aim is to examine how creative modes of writing might facilitate new or different types of critical engagement with Shakespeare. What kinds of critical insights are made possible only or especially via creative strategies? And, indeed, how do critical perspectives impel creative (re)engagement with Shakespeare?

I (Rob) say $a$ beginning because there are multiple origin stories to this overall story. To (hesitantly) begin with, the abstract (above) for the seminar I convened at the 2014 Shakespeare Association of America (SAA) conference in St Louis went through several drafts. The Trustees, perhaps quite sensibly, didn't quite trust that there were enough scholars out there quite as out there as I was. They wanted me to run a seminar which included critical accounts of creative work and not necessarily the integrated/both kinds of approaches I was hoping to solicit. After considerable back and forth they relented and the seminar papers responding to the call above perhaps both confirmed and dispelled the Trustees' initial uncertainty. Some contributors wrote fine critical articles about creative responses to Shakespeare (they are not included here). Some planned very interesting creative critical pieces but were thwarted by the creative practice - through failure to obtain performance rights or through the non-running of a creative writing graduate class - that they were depending upon not, at last, materializing (also not included). But some answered the call I made in ways that still delight and intrigue me (more on them below). 
One of those seminarians was me (Scott) and I eventually contributed what I called a 'fragment from a fictional future Arden edition'. But it took some time to get from my initial impulse to that final idea. I'd long been mulling over Elizabeth King's account of how the sixteenth-century Court Clock Master to the Holy Roman Emperor engraved his astronomical clock with an inscription reading: 'QVI. SIM. SCIES. SI. PAR. OPVS. FACERE. CONABERIS.' (or, in King's translation, 'You will know who I am if you try and make this') ${ }^{1}$ and wondering how that challenge might apply to our scholarly attempts to understand and appreciate Shakespeare. For Rob's seminar, I first proposed getting to know Shakespeare by 'writing Shakespeare' (as distinct from 'writing about Shakespeare') and making bold to produce one or two scenes that he 'could have' which is not to say 'would have' or 'should have' - written. I started writing my first scene about a middle-aged nurse cum nun in an early modern hospital cum monastery. Quickly, I realized that I knew precious little about nurses or hospitals in Shakespeare's time. I wondered whether Shakespeare himself knew any more than I did. When did the word 'nurse' become associated with today's modern medical profession? Consulting the Oxford English Dictionary, I was a bit surprised (and a bit sceptical) to find Shakespeare credited with the first use of 'nurse' in this sense. What about the word 'hospital'? How often - and in what contexts - did Shakespeare use it? That was when I realized that Shakespeare concluded Love's Labour's Lost with Berowne agreeing to 'jest a twelvemonth in an hospital'. Here was something Shakespeare could have written: Enter Nurse, the long-lost sequel to Love's Labour's Lost and, as it turned out, the porny but poignant prequel to Romeo and Juliet.

Following Rob's lead, I proposed my own seminar, 'Shakespearean Scene-Writing', for SAA 2015, which met with universal enthusiasm from that year's Trustees, with one caveat: I was advised 'this should probably be a workshop because the things produced are not standard scholarly product'. Here's a description of the workshop - newly imprinted and enlarged to almost as much againe as it was, according to the true and perfect coppie - as it appeared in the June 2014 SAA Bulletin:

Are there limits - and alternatives - to what criticism and commentary can teach us about Shakespeare? What if knowing why Shakespeare made use of adaptations, allusions, asides, backstory, characters, costume, cued parts, dancing, dialogue, disguise, duels, dumbshows, eavesdropping, 
ekphrasis, entrances and exits, flora and fauna, foreshadowing, ghosts, hendiadys, insults, irony, letters \& messengers, midline switches, music, noise, pacing, parody, plays-within-plays, plots, props, prose, proverbs, short lines, silence (or implied pauses), songs, time schemes, even lacunae and cruces as he did depended on learning how (or at least trying) to do it ourselves? Drawing on humanist methods of imitatio and early modern 'maker's knowledge traditions', this workshop will require participants to create new 'Shakespearean' scenes with period-specific diction, grammar, and iambic pentameter. Finally, since Shakespeare wrote in collaboration with other playwrights, participants should feel free either to write alone or to form groups of two or more 'hands'. Responses may include scholarly notes, readings, performances.

What I got in response to this call for papers was indeed 'not standard scholarly product', but instead an embarrassment of riches, the most creative set of abstracts I had seen in my dozen years of attending the SAA conference.

This was creative writing informed by literary criticism - literary creaticism? - and the possibilities made me very excited. I doubted that any members of the workshop would be interested in writing more than a scene or two - after all, we all had 'real work' to do - but I decided to share with them my ultimate fantasy: I imagined having a team of twelve scholars (and/or playwrights) agree to write three plays each - a comedy, a history, and a tragedy - over the course of the next several years so that we would have thirty-six new plays, a new Folio, to be published in 2023 to mark the four hundredth anniversary of the First Folio. Imagine that: Shakespeare scholarship producing a monumental tome that is not of an age but for all time ...

The 'creative' and the 'Shakespeare' thirds of our title are, we think, obvious: but in what ways are the articles, stories and plays contained herein also critical? And what kinds of critique do they offer? One way of approaching these questions is to imagine alternative titles for this special issue. Almost all of the contributions here might, for example, be gathered under the more general heading of 'Shakespeare and Adaptation'. All of the contributions consider, with varying degrees of depth or 'fidelity', a Shakespearean source and adapt it into a new form. Like Djanet Sears's Harlem Duet and Paula Vogel's Desdemona: A Play about a Handkerchief, both included in Daniel Fischlin and Mark Fortier's Adaptations of Shakespeare, ${ }^{2}$ the subheading of which is A Critical Anthology of Plays from the Seventeenth Century to the Present (emphasis added), and both of which offer trenchant creative critiques of Othello and its 
afterlives, adaptations here offer similar ripostes to cultural constructions of identity propped up by Shakespeare's dated universalism. (I, Scott, am appending this parenthetical aside to Rob's preceding sentence, to note that I find nothing dated but, contrarily, something dateless in what Kiernan Ryan calls 'Shakespeare's Universality'; moreover, the initial action of Enter Nurse aims to uphold Ryan's theory of Shakespearean comedy as 'exalt[ing] the humble [and] "giving the greater honour to the inferior part"'.) ${ }^{3}$ Jessica McCall and Kavita Mudan Finn, whose contributions to this issue slide perhaps from the dateless (doubly resonant for McCall's high school-set short story) to the dated end of the Shakespeare's universalism spectrum, and who coauthor an introduction to their respective fanfic pieces, aim their critical creative sights at normative representations mainly of sexuality and gender, but also of dis/ability and race.

'Shakespeare and Fanfiction' is another viable alternative title for this issue. Not just these prose pieces just mentioned, set respectively in an American high school and in a CSI-like New York City, but also in the four dramatic contributions to the issue. With a fervour equal to that early fanfic author, Maurice Morgann, but with perhaps greater self-reflexivity, each of these play fragments draws much closer, assuming their hitherto separation, the worlds of fanfiction and academia. Peter Holland writes of these converging worlds:

Fan studies are often concerned to distinguish between the fan and the academic. But Henry Jenkins, a principal figure in the study of fans and of convergence culture, describes himself as an 'Aca-fan', 'a hybrid creature which is part fan and part academic', and sees his own writing $\ldots$ as an attempt to bridge the two ... . If the distinguishing features of fandom include attending conventions and accumulating souvenir materials, often, in the high-brow fan, materials that are offered as ironic commentary on the subject, then almost all Shakespeare scholars must be fans as well as academics, with the strict proviso that ... we do not dress up as characters in our beloved works. ${ }^{4}$

Beloved characters are dressed up in and through the dramatic fanfiction offered here, the creation of which generates its own souvenir material, lost and rediscovered fragments from an alternative Shakespearean universe.

A special critique these fanfic plays make is of the academy itself, of the seriousness with which it conducts, monitors, and regulates itself, and particularly in terms of the demands of publication. Both 
Scott Maisano (this is Rob writing) and David Nicol take very funny and well-aimed shots at the Shakespearean editing Goliath: their pieces do not just re-create (and re-critique) Shakespearean drama, they also offer editorial, Arden 3-like notes, and often to hilarious effect. Indeed, the former's Enter Nurse, or Love's Labour's Won contains a glossarial explication of its dramatis personae almost as long as the dramatic verse that follows it, and the latter's $A$ Tragedy of the Plantation of Virginia (1623) is prefaced by an Eco-like introduction to its elusive textual status and the inclusion, in the marginalia, of disapproving and corrective notes from the Master of the Revels. These writings, and those by Mary Baine Campbell and Dan Moss, are funny. They are, we hope, a pleasure to read, even as they were a pleasure to write: and this writing-pleasure, we think, offers its own critique of academic endeavour, in particular, of publishing.

In the first (closest example to a conventional) article in this issue, 'Responses to Responses to Shakespeare's Sonnets: More Sonnets', Matthew Zarnowiecki describes his encounter with The Sonnets: Translating and Rewriting Shakespeare, 154 separate (broadly defined) poetic replies to Shakespeare's Sonnets, thus: 'the effect, in terms of my own reading activity, is double-booked'. Further, the effect of the double-booked effect, of having both books open and going back and forth between them, is that 'They both go both ways: each one deepens the other'. The contributions to this issue repeatedly offer the pleasures and rewards of double-booking: Kavita Mudan Finn's Pickled Red Herring made me (Rob) wide-eyed with admiration for the economy of its (and Shakespeare's) plotting and structure and for its commentary on Richard III, its various histories (1480s, 1590s, 2010s), and the processes of literary adaptation. And the other submissions herein invite the reader into immersive, creative critical, and double-booked engagement with new Shakespearean worlds: ancient Egypt; Jacobean London; Greek myth mashed with fairy tale; and perhaps that most dangerous and foreign of all worlds, junior high.

In Mary Baine Campbell's Echo and Narcissus, Little Red, like the pair(s?) of lover(s?) she comments on, is at once 'a child "on the brink of adulthood"' and an archetype predating any proper author. Her interrogative 'bow-wow' echoes Echo's '-Ow-,-Ow-', with a reverb distortion effect that reminds us (as Echo does time and again) how easily semantics can slip off to reveal bare sound. In Dan Moss's The 
Fair Maid of Alexandria, 'The Persons of the Play' are nearly all notorious figures who bring their own 'instant backstory' to the drama. One can hardly wait to see what Shakespeare would do with Herodotus, Solon, Hermes Trismegistus, Callimachus, and Nefertiti. Will they fulfil or subvert an audience's expectations? The notes included in David Nicol's A Tragedy of the Plantation of Virginia, like Will Summer's running commentary throughout Summer's Last Will and Testament (Thomas Nashe, 1600), serve to (1) anticipate and forestall some of the audiences' or readers' questions and/or objections; (2) supply a refreshingly modern counterpoint to the early modern rhetorical fireworks; (3) meet the audience halfway between the fictional and real worlds; and (4) compete for attention with the play they alternately elucidate and obfuscate. These fauxShakespearean dramas play games with history, with time travel and anachronism, and so the last contribution, Rob Conkie's 'Othello, Original Practices: A Photographic Essay', corresponds with Henry Jackson and with the 1610 Oxford production of Othello that Jackson describes.

We do not wish to suggest that here is the beginning of Creative Critical Shakespeares - they have multiple origin stories, too. We follow in the footsteps of series like Shakespeare Now!, we seek creative collisions and try to tell tales from Shakespeare like Graham Holderness, ${ }^{5}$ and we aim to write performatively, ${ }^{6}$ with passion and with purpose. We continue the work in issue 25.3 of this very journal which was intent on 'dismantling barriers ... between intellectual enquiry and imaginative recreation'. ${ }^{7}$ And neither is the work in this issue necessarily finished. Kavita Mudan Finn has already added a fourth to the three chapters of Pickled Red Herring published here (and the rest are on the way) and Rob has promised Scott to direct Enter Nurse as soon as it is finished. We look forward to further work in this field, such as other Shakespearean scenes, not able to be included here, by Paul Menzer, Eric Binnie, Douglas Green, Douglas King, and Brian Knight, or perhaps spurred by a third and upcoming conference, the World Shakespeare Congress on 'Creating and Recreating Shakespeare'. That this issue has been framed by three conferences (from 2014, 2015, and 2016) attests to the dialogic, collaborative, and iterative dimension of the work contained herein: here's your invitation to join this particular, but by no means exclusive, conversation. 


\section{Notes}

1. Elizabeth King, 'Perpetual Devotion: A Sixteenth-Century Machine That Prays', in Genesis Redux: Essays in the History and Philosophy of Artificial Life, ed. Jessica Riskin (Chicago: University of Chicago Press, 2007), 274.

2. Daniel Fischlin and Mark Fortier, eds, Adaptations of Shakespeare: A Critical Anthology of Plays from the Seventeenth Century to the Present (London: Routledge, 2000).

3. Kiernan Ryan, Shakespeare's Universality: Here's Fine Revolution (London: Bloomsbury, 2015); Kiernan Ryan, Shakespeare's Comedies (New York: Palgrave, 2009), 95 .

4. Peter Holland, 'Spinach and Tobacco: Making Shakespearian Unoriginals', Shakespeare Survey 68 (Cambridge: Cambridge University Press, 2015), 197-209, 206.

5. Graham Holderness, Tales from Shakespeare: Creative Collisions (Cambridge: Cambridge University Press, 2014).

6. Rob Conkie, Writing Performative Shakespeares: New Forms for Performance Criticism (Cambridge: Cambridge University Press, 2016).

7. Graham Holderness, 'Introduction', Critical Survey 25, 3 (2013), 1-3, 3.

Rob Conkie is Senior Lecturer in Theatre and Drama at La Trobe University, Melbourne, Australia. He integrates practical and theoretical approaches to Shakespeare in performance. He is the author of Writing Performative Shakespeares: New Forms for Performance Criticism (Cambridge, 2016) and The Globe Theatre Project: Shakespeare and Authenticity (Edwin Mellen, 2006), as well as numerous articles in Shakespeare-themed journals and edited collections. He has directed about one third of the Shakespeare canon.

Scott Maisano is Associate Professor of English at the University of Massachusetts Boston. His publications include "Shakespeare's Revolution: The Tempest as Scientific Romance," about Prospero and particle physics in The Tempest: A Critical Guide (Bloomsbury Arden Shakespeare); "Now," about Einsteinian spacetime in The Winter's Tale, for Early Modern Theatricality (Oxford University Press); "Rise of the Poet of the Apes," about intelligent apes and monkeys in plays from the beginning to the end of Shakespeare's career, for Shakespeare Studies; and "Seen / Not Seen," about obscene matters in A Midsummer Night's Dream for iPad (Luminary Digital Media). He has coedited Renaissance Posthumanism (Fordham University Press) with Joseph Campana and is writing a new Shakespearean comedy entitled Enter Nurse, or, Love's Labour's Won. 